\title{
Key Attributes of Designers' Competency for Prevention through Design (PtD) practices in Construction: A Review
}

DOI:

10.1108/ECAM-04-2020-0252

\section{Document Version}

Accepted author manuscript

Link to publication record in Manchester Research Explorer

\section{Citation for published version (APA):}

Che Ibrahim, C. K. I., Belayutham, S., Manu, P., \& Mahamadu, A. M. (2020). Key Attributes of Designers' Competency for Prevention through Design (PtD) practices in Construction: A Review. Engineering Construction and Architectural Management. https://doi.org/10.1108/ECAM-04-2020-0252

\section{Published in:}

Engineering Construction and Architectural Management

\section{Citing this paper}

Please note that where the full-text provided on Manchester Research Explorer is the Author Accepted Manuscript or Proof version this may differ from the final Published version. If citing, it is advised that you check and use the publisher's definitive version.

\section{General rights}

Copyright and moral rights for the publications made accessible in the Research Explorer are retained by the authors and/or other copyright owners and it is a condition of accessing publications that users recognise and abide by the legal requirements associated with these rights.

\section{Takedown policy}

If you believe that this document breaches copyright please refer to the University of Manchester's Takedown Procedures [http://man.ac.uk/04Y6Bo] or contact uml.scholarlycommunications@manchester.ac.uk providing relevant details, so we can investigate your claim.

\section{OPEN ACCESS}




\section{Engineering Construction and Architectural Management}

\section{DOI: 10.1108/ECAM-04-2020-0252}

\section{Key Attributes of Designers' Competency for Prevention through Design (PtD) practices in Construction: A Review}

Che Khairil Izam Che Ibrahim ${ }^{1 *}$, Sheila Belayutham ${ }^{1}$, Patrick Manu² and Abdul-Majeed Mahamadu $^{3}$

1 Faculty of Civil Engineering, Universiti Teknologi MARA, 40450 Shah Alam, Selangor, Malaysia

${ }^{2}$ Department of Mechanical, Aerospace and Civil Engineering, The University of Manchester, M13 9LP, Manchester, United Kingdom

${ }^{3}$ Department of Architecture and the Built Environment, University of the West of England, Bristol, BS16 1QY, United Kingdom

*Corresponding author.

Telephone: +60124947874

E-mail addresses: chekhairil449@uitm.edu.my 


\section{Abstract}

Purpose - Designers have a key role to play in the Prevention through Design (PtD) practices in construction projects. Nonetheless, previous studies indicated that the issue of competencies to perform and sustain such practices over time is of a significant concern. This study aims to explore the key attributes of designers' competencies for PtD practices in construction.

Design/methodology/approach - By using the Scopus database, a total of 88 papers related to $\mathrm{PtD}$ in construction published in peer-reviewed journals were reviewed and analysed using the well-established systematic literature review (SLR) methodology.

Findings - The review indicates that in order to be competent in PtD implementation, designers need to be equipped with tacit and explicit knowledge; technical and soft skills; and experience related to PtD. Furthermore, the review identifies attributes of these competencies. Additionally, a framework that links key PtD elements/principles with the PtD competencies is presented.

Practical implications - The findings would enable contribution to the industry by providing the necessary references for design organisations to improve their designers' PtD competencies and hence, be able to meet their responsibility under relevant occupational safety and health (OSH) legislative framework.

Originality/value - This study extends the PtD literature in the construction context by providing deeper insights into the conceptualisation of relationship between competent designers and PtD elements. The novelty also lies in the consolidation of PtD competency attributes for designers in construction that could act as a reference for any future developments related to PtD competency assessment for designers.

Keywords: Prevention through Design, Competency, Designer, Safety, Construction 


\section{Introduction}

The construction industry has been perceived as one of the most hazardous industries, highly susceptible to workplace accidents. In construction, decisions that frame the design and constructability of a project, that directly affects the safety outcomes are made even before the construction works begin. Construction safety literatures across the world have indicated the strong link between design and the occurrence of injuries and accidents in construction (Behm, 2005; Manu et al., 2014; Toh et al., 2017; Hardison and Hallowell, 2019). For instance, a recent study of subway projects in China by Xiahou et al. (2018), found that $53 \%$ of the accidents could be linked to safe design. Studies by Driscoll et al. (2008) and Hui (2015) found that 44\% of construction fatalities were 'design-related' in Australia and Singapore, respectively. In general, the recorded percentage of construction accident cases associated with permanent works design ranges between $40 \%$ to $70 \%$ (see Che Ibrahim and Belayutham, 2020), highlighting that decisions made by designers at the design phase could have significant implications for the safety of workers. Consequently, the interest on Occupational Safety and Health (OSH) practices, particularly in regards to the involvement of designers (for proper implementation of OSH at construction sites) has grown in various countries. The involvement of designers in OSH has long been recognised by Szymberski (1997) through his time-safety influence curve, where he has emphasised that safety practices could be greatly influenced in the early stages of project (i.e. design stage) and such influence fades towards the end of construction.

Several efforts and initiatives known as Prevention through Design (PtD) in the US, Design for Safety (DfS) in Singapore, Construction Design and Management (CDM) in the UK and Safe Design in Australia have been introduced to encourage designers to incorporate OSH to eliminate or reduce construction site hazards during planning and design phases. Also, the institutional pressure introduced by incorporating these initiatives as guidelines (e.g. US, 
Hong Kong and Malaysia), as well as regulatory frameworks (e.g. in several European countries such as UK and Ireland, as well as in other countries such as Australia and Singapore) has served as stimuli for designers to enhance and improve their capability to mitigate health and safety risks through design.

Despite the plethora of efforts in several geographical contexts to understand the concept, processes and practices of this promising approach (e.g. PtD, CDM, DfS), there are still limitations in understanding the designers' capabilities that affects their professional competencies towards its implementation. As emphasised by Manu et al. (2019a), comprehensive insight into what constitutes designers' capabilities towards OSH is limited. The possible reasons that contribute to these limitations are the misconceptions and mind set of designers, particularly having the view that safety issues are complex in construction (e.g. design task, OSH assessment of a design) (Behm et al., 2014; Goh and Chua, 2016; Edirisinghe et al., 2016; Manu et al., 2018), insensitive to workers' exposure to safety hazards (Sacks et al., 2015) and the lack of knowledge and understanding on the roles and responsibilities of designers in addressing the OSH issues during the design phase (Gangolells, et al., 2010; Morrow et al., 2015). The lack of prevention-based education at the tertiary level often leads to inadequacy in embracing the knowledge of the concept (Popov et al., 2013; López-Arquillos et al., 2015; Abueisheh et al., 2020). On the other hand, limited availability of PtD related tools, guidelines and techniques have hindered the designers to enhance their skills to practice this concept during design (Jin et al., 2019). Furthermore, the lack of codification and regulation for PtD in several countries often contributes to the inability of designers to enhance their PtD skills. Another reason for the lack of designers' capabilities is due to the lack of experience in practicing such concept. As PtD concept is about embracing collective efforts, the traditional approaches of procurement and contracting does not provide a conducive avenue to promote positive experiences (in terms of ownership and joint responsibility) in delivering a safety- 
conscious ecosystem throughout the life cycle of a project (Gambatese et al., 2017). The existing characteristics of project teams (e.g. different organisational and professional interests, varying levels of knowledge and experience) certainly affects the efforts towards developing a collective approach in managing OSH (Lingard et al., 2015).

It is worth noting that the current legislation, for example in the UK, CDM regulations 2015; in Ireland, the Safety, Health and Welfare at Work (Construction) Regulations 2013; in Singapore, the Workplace Safety and Health Regulations 2015; and in Australia and New Zealand, Work Health and Safety Acts and Regulations have highlighted the importance of appointing a competent designer with adequate knowledge, skills and experience related to OSH. In addition to this legislative framework, studies (e.g. Gambatese et al., 2017; Manu et al., 2019a) have indicated that having competent designers is crucial as the risk created during construction can be linked to designs and therefore designers should thoroughly understand the way buildings or structures can be constructed, maintained, and demolished safely.

Although a great deal of attention (highlighted in the guidelines and regulations) has been given to the needs of having competent designers, studies focussing on providing comprehensive understanding of the dimensions of designers' competencies from the OSH perspective are limited. As a result, there is no consolidated information on the key PtD attributes for designers' competencies for construction. While the focus on organisational design for safety capability is growing (e.g. Manu et al., 2019a; Poghosyan et al., 2020), there has not been a systematic review of designers' competencies, particularly in providing a comprehensive insight into the key attributes of designers' competencies for PtD. In order to address this gap, this paper focuses on identifying the key attributes of designers' competencies for $\mathrm{PtD}$ practice in construction and attempts to classify the attributes, with the intention of gaining a greater insight into how those attributes could influence the PtD practice. The fact that designers' consideration of construction safety has been mainly discretionary, particularly 
in the absence of relevant knowledge and practices (i.e. know-how) (Hinze and Wiegand, 1992; Che Ibrahim and Belayutham, 2020), such attributes could act as a point of reference that could further instil and encourage the preventive culture among design professionals. Moreover, clients could use such reference to assess and appoint designers based on the PtD capability (i.e. ability of a designer to explicitly consider OSH in their design decisions and hence protect OSH of builders and maintenance workers) (Manu et al., 2019a). As emphasised by Manu et al. (2017), any research related to professional capability towards safety is critical as it will not only help to fulfil and ascertain designers' responsibility under stipulated regulations, but also contribute to the continuous improvements of safety practices by considering safety measures at early stages of construction.

\section{Research Method}

This study has adopted a systematic literature review (SLR) approach to review studies conducted on the subject of Prevention through Design (PtD) in the construction domain. This method involves a comprehensive approach (i.e. involving the activities of searching, inclusion criteria, data extraction and synthesis) to capture works focusing on the specific context and further synthesising the findings into several perspectives depending on the objective of the study (Ibrahim et al., 2013; Raouf and Al-Ghamdi, 2019)

In this regard, a similar three-stage (i.e. identification of academic journals, selection of target papers and examination of the target papers) search process used by Osei-Kyei and Chan (2015) was adopted to conduct a content analysis of the key PtD attributes of designers' competencies in construction. A framework of this approach is shown in Figure 1.

\section{Stage 1: Database and Journal Selection}

In Stage 1, the Scopus database was selected due to its ability to perform better than other search engines in terms of its coverage and accuracy (Yi and Yang, 2014). Being the largest 
database, Scopus have also been utilised in many recent review studies in the construction domain, for example, in construction safety (Jin et al., 2019), green building (Darko and Chan, 2016), risk identification (Siraj and Fayek, 2019), Building Information Modelling (Jin et al., 2019) and public-private partnerships (Narbaev et al., 2019). As the first step for this approach, the "Scopus" search engine was used to perform the search via "titles/abstract/keyword".

\section{'Insert Figure 1'}

Document type was set as "article or review" while keywords of "prevention through design", "safety by design", “construction design management", "design for safety”, "safety in design”, "design risk management" and "construction" were included in the initial search to identify papers. The complete search code is listed as follows:

TITLE-ABS-KEY ("prevention through design" OR "safety by design" OR "Construction Design and Management" OR "design for safety" OR "safety in design" OR "design risk management" AND "construction")

Considering the fact that this study intents to analyse PtD-related construction literatures, the above-mentioned keywords were set broad to capture a bigger perspective of PtD-related concept, application and processes in the construction context. It also testifies the level of attention the subject attracts in the construction engineering and management (CEM) research, as well as establishing boundaries of the study. Following the keyword input, the screening of the publication source was limited to journals written in English. In addition, relevant leading CEM journals such as Journal of Construction Engineering and Management, Engineering, Construction and Architectural Management, Automation in Construction, Safety Science, Construction Management and Economics, Proceedings of the Institution of Civil Engineers: Civil Engineering and Architectural Engineering and Design Management and 
conferences were selected. Also, the title and abstracts in other relevant journals and proceedings were screened to ensure its relevancy to this study. This search exercise from Scopus was performed in December 2019 and covers articles published until year 2020. Overall, the initial search returned 305 papers and reduced to 183 papers, from 91 different publications (i.e. journals and proceedings) after the first screening, as shown in Table 1.

\section{"Insert Table 1"}

\section{Stage 2: Article Selection}

After the initial identification of articles, the next step of article selection was performed to screen the articles. The following inclusion criteria were used to select the articles: (1) the article should be specifically related to PtD practices in the construction industry; (2) the article should focus at least on either the concept, application or process of PtD in construction; and (3) the article should mention any discussion related to the competency or capability of designer. Publications which do not contain the above-mentioned criteria were screened out. Also, through screening, some articles that were not relevant were also excluded, for example, article in which the authors mainly emphasised on different context such as blockchain technology and fire design which are beyond the scope of this study. At this stage, conference papers were excluded in this exercise due to the lack of information provided, shorter version from the published journal (Jin et al., 2019), as well as the standards of publication (e.g. peer review process) that are highly variable and difficult to measure (Hardison and Hallowell, 2019). Consequently, the contents of the articles were examined, and the number of articles were further reduced to 79, which were then used for the content analysis in identifying the key PtD attributes of designers' competencies in construction.

In addition, the snowball method of identifying relevant articles that have not been captured by the Scopus database has also been conducted, resulting in additional 9 articles from 
journals. This exercise was conducted to enrich findings from the first two-stage search, in order to obtain a comprehensive coverage of the papers that are worth reviewing. The snowball exercise suffices because it provides an opportunity to include the significant state-of-the-art works related to the study (Li et al., 2019).

\section{Stage 3: Content Analysis}

After considering the works of Ibrahim et al. (2013), a qualitative content analysis, using rhetorical analysis was adopted to identify what it takes (i.e. key attributes) for designers to be competent in practicing PtD. Krippendorff (2013) emphasised that efforts to study the identification of attributes and examining its trends and patterns within a specific context could be done through the content analysis technique. Fellows and Liu (2015) further described that any categorisation should be exclusive (i.e. where data is assigned to one category) and exhaustive (i.e. categories cover the research topic comprehensively). In stage 3, after the identification and selection of the related articles, detailed content analysis was carried out in order to (1) profile the selected articles based on its subject / context and geographical region; (2) examine the relevant key PtD attributes of designers in the selected articles; and (3) systematically categorise the key attributes based on their characteristics. It is worth noting that any numerical values or descriptive discussion related to the PtD attributes were determined based on the final number of articles considered in the content analysis (i.e., 88 articles). Once the papers were reviewed and classified, they were summarised in accordance to the specific category.

\section{Results and Analysis}

Following a comprehensive content analysis, the key PtD competency attributes of designers were identified and categorised based on their nature. The review and discussion of the designers' PtD competency attributes were bounded within the context of definition provided 
by Quinn et al. (1996) on competency. For this study, the PtD competency can be defined as 'possession of knowledge, skills and experience capacity by the designer to perform PtD practice appropriately and adequately'. Consequently, the key PtD competency attributes in this study are defined as determinant factors associated with the relevant knowledge, skills and experience for designers to focus on practicing PtD in their tasks. Table 2 outlines the key terms and definitions used in the study.

\section{"Insert Table 2"}

It is worth noting that while there is a complex relationship between knowledge, skills and experience (for instance, knowledge and skills could be gained through experience, and development of skills would require specific knowledge), the need to consider them independently is crucial because each these represent a key element of designers' competency. For example, a designer might have knowledge of construction hazards. However, having such knowledge is the first step; whether or not the designer has the hazard recognition skills depends on other factors (e.g. through consistent training and mnemonics technique) (Hallowell and Hansen, 2016). Similarly, a construction personnel might have a specific OSH knowledge, but the personnel might not be able to extend the practicality of the knowledge to others if he/she is not experiencing the real events on the given subject (Lingard and Wakefield, 2019). On the other hand, a designer may have the knowledge, however, he might not be able to demonstrate the skills of applying that knowledge in a specific context. The lack of knowledge in a particular subject may also be alleviated if a designer has the ability to use safety tools that have databases of design alternatives to help guide the decision-making process (Toole, 2005). Consequently, there is no interchangeably between knowledge, skills and experience for designers in PtD implementation (Manu et al., 2019b; Che Ibrahim and 
Belayutham, 2020). This is consistent with related PtD regulations and guidelines (e.g. CDM Regulations 2015 (Health and Safety Executive, 2015); Guidelines of Occupational Safety and Health in Construction Industry (Management) 2017 (DOSH, 2020)), where designers are expected to be competent in terms of their knowledge, skills and experience in fulfilling their role and responsibilities related to $\mathrm{OSH}$.

In principle, the $\mathrm{PtD}$ competency attributes identified from the final selected 88 articles were grouped into three main categories: knowledge, skills and experience and were then sub divided into specific sub-categories depending on the relevancy of the attributes (see Table 3). The following sections briefly discuss each of these key attributes.

\section{Knowledge}

The need for PtD knowledge is well recognised as the critical element to define the competency of a designer. PtD researchers have indicated that the profound lack of knowledge to practice PtD among construction design professionals are compelling (Gambatese et al. 2017; Che Ibrahim and Belayutham, 2020). It has been suggested that the understanding of PtD has long been associated with the nature of construction lifecycle. The complex nature of construction, in terms of technological and social requires wide range of knowledge to be dealt with. Such characteristics, together with the inability to possess specific knowledge were thought to have contributed to the disproportionate high rate of injuries and accidents in construction (Sherratt and Ivory, 2019).

Several scholars (e.g. Addis, 2016; Yuan et al., 2019) have highlighted that in the construction domain, in particular, within the context of construction safety risk management, knowledge can be divided into two; explicit knowledge and tacit knowledge. By definition, tacit knowledge is personal know-how (practicality), largely acquired through education, training and experience, while explicit knowledge is personal know-that (theoretical), formally 
articulated in guidelines, procedures and best practices (e.g. regulations, code of practices, specifications, drawing) (Addis, 2016).

\section{"Insert Table 3"}

\section{Tacit Knowledge}

In terms of the tacit PtD-knowledge, most of the literatures indicated that the instance of tacit knowledge could range from the design aspect to construction landscape. In particular, although the knowledge on design features (e.g. structural elements, parameter, functional constrain) is the norm of practice, the complexity and diversity of construction underpins the extensive emphasis about the importance of construction knowledge. Construction knowledge frequently involves knowledge on construction methodology (e.g. in-situ and off-site production, demolition works, construction sequencing, work level; component scale, location of installation) (Melzner et al., 2013; Foncesa et al., 2014); site characteristic (site location and surroundings such as wind, environmental, building features, transportability); construction site layout issues such as terrain, site logistics, (Zhang et al., 2015), accessibility (Lingard et al., 2013) and construction site operations such as moving parts of machinery (Gangolells et al., 2014). This is further supported by Ho et al. (2020) who emphasised that different application of PtD need different knowledge on its design feature and the constructability. For example, they found that for PtD application in solar project, seven PtD attributes (roofing material, roof slope, roof access, panel layout, fall protection system, lifting method, and electrical system) are required. Also, knowledge related to the management of temporary and permanent electrical power, safety when moving from de-energized equipment to energized equipment, and safety during commissioning are also important to the designers (Crow et al., 2015). Identifying the characteristics of practical knowledge that can influence constructability of a project, as well as the integration between multi-organisations could reduce the risk of OSH incidents (Toole, 2005). 
On the other hand, the assessment of knowledge on designers' hazard recognition is critical to ensure high-quality safety decision being made during design (Hallowell and Hansen, 2016). Previous studies have highlighted that both types of hazard, latent and patent is important for PtD practices. Patent hazards such as construction hazard, electrical hazard, spatial hazard and maintenance and operation hazard are identifiable at early stages of construction. This is supported by a recent study by Hallowell and Hansen (2016), where the findings indicated that approximately $75 \%$ of patent hazards are identifiable during the design phase. Moreover, construction site hazards (e.g. working at height, confined space) are commonly known to be patent hazards due to the fact that these hazards tend to be more obvious and are closer to accidents or adverse health and safety outcomes (Haslam et al., 2005; Manu et al., 2012).. In contrast, design related hazards are known as latent hazards due to their underlying/distal nature in the process of accident causation (Haslam et al., 2005; Manu et al., 2012). The complexity and multi-causal nature of accidents is also an issue worth knowing by designers (Haslam et al., 2005; Manu et al., 2012). For example, Manu et al. (2012) explained that some construction project characteristics (e.g. pre-assembly method of construction) can mitigate the patent accident causal factors induced by other project characteristics (e.g. a restricted site, which induces site congestion). Acknowledging various types of hazards could provide key information to facilitate the PtD implementation, particularly for effectiveness of the control measures (i.e. elimination, substitution, engineering controls, administrative controls and personal protective equipment). For instance, the spectrum of exposure to a hazard in the operation/maintenance stage of a facility could have different implications, as compared to short term exposure to a hazard in the construction stage (Lingard et al., 2015). The ability to recognise hazards and its control measures in different phases of construction projects could facilitate decision making (e.g. the relative magnitude of the risk in each stage of the life cycle) 
during the safety review process (Lingard et al., 2013; Hardison and Hallowell, 2019) and ensuring the effectiveness of the measures (Zhao et al., 2015).

\section{Explicit Knowledge}

Despite much of the knowledge in construction is experience-based and tacit, the need for explicit knowledge is also vital, as a strategy for knowledge management in the industry (; Addis, 2016). As for PtD, explicit knowledge in terms of the PtD concept itself is well acknowledged for its importance due to the influence on designers' capability in embracing the concept. The characteristic of PtD which incorporates hazard prevention in the design process, with an emphasis on maximising OSH over the lifecycle of a project warrants the need for wider context of knowledge. Knowledge on the PtD principles itself is critical as the foundation of the designers' understanding on the concept. Previous scholars have also indicated that PtD is a multi-dimensional knowledge and its diffusion relies on diverse topics such as social sustainability, ethics, integrated design and construction and lifecycle analysis (Toole, 2017). The importance of engineers' ethics towards OSH has been highlighted in many professional codes of ethic (i.e. relates to the safety, health, and welfare of the public) and the ability to link such PtD knowledge and their ethics could lead to the effectiveness of the OSH practice. Designers have to be sensitive in designing for buildings that are not only safe to be operated, but also safe to be built. Such integration of the design and construction context could facilitate the designers' capability to the next level of OSH practices.

Expanding designers' knowledge on the collaboration is vital as collaborative practices have a greater presence and importance in $\mathrm{PtD}$ implementation. As collective responsibility is the backbone of $\mathrm{PtD}$ practice, understanding collaborative ways of working/procurements (e.g. Integrated Project Delivery (IPD), partnering, alliance, early contractor involvement (ECI)) underpinned by collaborative philosophy, as well as integration of contractors' perspectives at 
the early phases could facilitate the development of PtD decisions. Studies (e.g. Webster, 2013; Che Ibrahim and Belayutham, 2020) have indicated that the characteristics (e.g. early integration between parties, risk and rewards, flexibility, opportunity to innovate) of collaborative procurement allows designers to recognise construction site safety and constructability as a part of design criterion during the planning phase. This is supported by Hare and Cameron (2012) where such procurement could facilitate early integration of health and safety, focusing on collaborative risk assessment. Such integration and collaboration are important as designers normally have insufficient practical knowledge of unplanned activities of construction and operation (e.g. to coordinate different sub-systems, maintenance accessibility, and dynamic loads during construction (Larsen and Whyte, 2013). On the other hand, contractual considerations by the designers is also needed due to the increased potential liabilities and the scale of multi-party contracts. Also, designers should also understand the wide range of contractual dimensions, such as the work scope, indemnification clauses, limitation of liability provisions, construction observation requirements, and dispute resolution methods.

Another explicit knowledge required by the designers is the ability to understand the related OSH and PtD legislative frameworks. Regardless of countries that have legalised or adopted PtD on voluntary basis, having knowledge of legal responsibilities of designers towards OSH could influence the attitude towards safety and eradicate the barriers towards PtD implementation (Sacks et al., 2015). The issue of responsibility in PtD practices could influence the ethical dimension of designers, which commonly hinges on prioritising end users OSH at the expense of the construction workers (Lingard et al., 2013). This is consistent with a recent study by Bong et al. (2015), where designers in Australia believe that regulations and codes of practice have a positive impact on their understanding towards construction safety.

\section{Skills}


Skills are known as the practical application of knowledge. In relation to PtD competency skills, two notable skill areas are presented in this paper, namely technical and soft skills.

\section{Technical Skills}

One of the most important technical skills cited in the literature is the hazard recognition skills. The ability of designers to forecast wide ranging potential hazards that could occur during construction and post-construction, based on the integration of their existing knowledge and design information is critical for high quality safety decision making at early stages of project (Hallowell and Hansen, 2016; Hardison et al., 2020). Fonseca et al (2014) added that the ability to anticipate hazards at several levels of construction could have positive influence on the production and safety performance. Also, hazard and risk analysis skills have been highlighted by many scholars as important skills as these are the core activities and processes involved in risk assessment. Several techniques have been applied in PtD practices such as preliminary hazard analysis (Lyon et al., 2016); risk-analysis based approach (Gangolells et al., 2010); what if/ checklist analysis; failure mode and effect analysis (Ezisi and Issa, 2018) and fault tree analysis. These analyses provide several advantages, such as simple methodology for lessexperienced designers to conduct initial assessment by comparing construction techniques and systems during the design phase and subsequently determining the corresponding level of safety risk (Gangolells et al., 2010). In addition, such analysis skills could lead to better decision making, especially in applying appropriate control measures (e.g. risk avoidance, mitigation or elimination) for hazards.

Studies have highlighted that apart from specific techniques to assist PtD, technologyenabled tools could further add value and maximise the potential benefits of PtD implementation. The rapid development of digital technologies, in particular building information modelling (BIM), virtual design and construction, and augmented reality (AR) 
offers opportunities for designers to better practice PtD (Gangolells et a., 2010; Hyne et al., 2017; Yuan et al., 2019). Nevertheless, as compared to the traditional technology (e.g. twodimensional plan, written specifications, method statement), these disruptive technologies vary greatly in format, content, and quality and quantity of information and could enhance designers' disruptive skills towards PtD. The information technology-enabled tools offer wide ranging opportunities to enhance $\mathrm{PtD}$ implementation. One of the most cited opportunity is the ability of the tool to provide better visualisation that could facilitate interactive design and dynamic construction environments (Hadikusumo and Rowlinson, 2004), stimulating discussion around salient features of a project (Edirisinghe et al., 2016). Visualisation of models (in two design areas: architectural construction details and detailed design of the building systems) is able to initiate collaborative movement between designers and contractors over time (Sacks et al., 2015). For example, BIM could be used for design inspections by conducting clash detection, hazard checking (Teo et al., 2016) and assessment of safety risk and hazard on key construction safety risks activities, e.g. work at height, confined space, excavations, demolition works, etc (Qi et al., 2014; Yuan et al., 2019). Similarly, virtual reality (VR) could improve designers' understanding on real construction processes (e.g. identify inherent hazard), as compared to traditional descriptive method statement (Hadikusumo and Rowlinson, 2004). Also, the application of VR or AR are able to digitally simulate the construction site context in which project teams could learn about safety hazards without physically exposing them to the hazards (Sacks et al., 2015). Furthermore, these emerging technologies could assist the safety risk mitigation in terms of its applications within each level of the hierarchy of control (e.g. BIM has significant effects on the elimination and substitution levels) across the project life cycle (Okpala et al., 2020). On the other hand, the use of digital technologies could also enhance decision making through the integration of information or knowledge-based input into a specific system. For instance, the use of BIM could also provide 
checking for compliance with specific safety requirements, thus allowing for better decision of the design, which results in enhanced construction site safety (Melzner et al., 2013), as well as the aspect of sustainability of a project (Dewlaney and Hallowell, 2012). It is worth highlighting that even though these tools could facilitate PtD implementation, the study by Mzyece et al. (2019) indicated that having BIM could only fulfil between 4 (18\%) to 9 (41\%) roles and responsibilities of designer and principal designer respectively, as stipulated in the CDM regulations.

The literature also cited that the capability of conducting cost-benefit analysis related to $\mathrm{OSH}$ could provide a guidance to decision making in regards to accident prevention. The need for designers to adapt to this skill is necessary, as a basis to derive financial benefits for the proposed control measures in the business case (Lyon et al., 2016). The potential increased direct and indirect costs associated with designers performing safety-related task could influence their professional fees (Toole, 2005). Also, the fact that the wide ranging construction activities may influence the estimated risk and hence, causes uncertainties to the associated cost, and the ability to conduct such analysis (e.g. cost of accident prevention) could ease the understanding on economic impact towards PtD (Dharmapalan et al., 2015). As cost is perceived as one of the major barriers for $\mathrm{PtD}$, an appropriate cost-benefit model (financial implications on PtD together with its benefits; e.g. diminishing project risk and increasing efficiency) could provide the means to assess $\mathrm{PtD}$ from a financial perspective, hence facilitating owners and designers in achieving an appropriate balance in design and making informed decisions while choosing the most economical PtD solutions (Rajendran and Gambatese, 2013; Lingard et al., 2019).

\section{Soft Skills}


Success in the PtD practice does not only depend on hard or technical skills. Soft skills with an emphasis on behavioural skill is another set of key skill, as cited in the literature. The consideration to integrate social factors in the PtD practice is important as this concept involves behavioral and emotional change (i.e. shifting from compliance to commitment) (Horberry, 2014). The most important skill is the collaboration skill, in particular skills that relate to relationship (e.g. communication, trust, leadership) that enables designers to engage with other professionals (e.g. client, contractor) productively and efficiently towards PtD practices. The integration of multiple areas (e.g. processes, scope and work conditions associated with the design and its risk) with different expertise in $\mathrm{PtD}$ could create unique solutions that lead to innovation, and hence achieving the goals and aims of the project (Gambatese et al., 2013; Morrow et al., 2015).

Given that the landscape of collaboration in $\mathrm{PtD}$ is beyond the design and planning phase, a holistic approach on relationship attributes is essential to ensure successful implementation of PtD. In particular, communication skill is critical to unfold the design decisions, clarify roles of stakeholders, interactions and interests on PtD (Lingard et al., 2012). This is supported by Gambatese et al. (2017) where effective and consistent communication between client and designers could change the mindset and behaviour of designers towards PtD.

This could be done through innovative approach, such as by using infographic to stimulate discussion and advance views into existing workflows on PtD (Edirisinghe et al., 2016). Another example is the need of collective leadership in the PtD implementation. Leadership plays a central role in establishing an appropriate organisational culture that influences PtD behavior (Gambatese, 2019). Setting high expectations on OSH and making $\mathrm{OSH}$ as a priority by the owner could demonstrate an act of leading by example for the other stakeholders (Toole et al., 2017). In addition, continuous team-work exercise could instil 
collaborative philosophy and establish trust in people and technology towards PtD in a very dynamic environment (Weidman et al., 2015; Che Ibrahim and Belayutham, 2020). Such attributes could be enabled through early appointment of contractors, establishment of collocated or one common office and information-enabled technology (Webster, 2013; Poghosyan et al., 2020).

\section{Experience}

The capabilities or proficiencies of a professional is developed through learning, training or hands-on experience. In the case of PtD, the need for the designer to have an experience in conducting design-related construction works is critical. This is because most of the designrelated OSH hazards are associated with the dynamic context of construction design (Lingard et al., 2013). In addition, such design experiences could provide different dimensions (format, type) of design information that facilitates the hazard recognition activities (Hardison et al., 2020). Also, the existing OSH regulations may not accurately reflect the dynamic nature of construction processes; and therefore, the experience of designers is needed to manage such complexity (Hadikusumo and Rowlinson, 2004). In addition, as design processes are digitally facilitated, having digital design experiences could enhance designers' visualisation and understanding of safety practices (Larsen and Whyte, 2013; Yuan et al., 2019).

The experience of working in different types of project could enhance the dynamism of the designers' capability towards the dynamic design processes (e.g. the complexity of project could lead to extensive design changes) (Larsen and Whyte, 2013). This is supported by Xiahou et al. (2018), where they emphasised that the nature of project, for example in subway project, the design activities have a greater influence on the operation, rather than the construction phase. In contrast, proactive actions on PtD practices is required in both stages (design and underground operations management) for hazard preventions (firedamp, asbestos, radioactive 
minerals, etc. due to geological reasons) especially for explosive activities of tunnelling (Labagnara et al., 2015).

While having experience by involving in any part of PtD processes (e.g. perform preliminary risk and hazard analysis, establish checklists) is certainly advantages, such involvement is known to be minimal due to the lack of institutional pressures in the construction industry (Che Ibrahim and Belayutham, 2020). Gangolells et al. (2010) further emphasised that experience in the PtD process could nurture the capability of less experienced designers on the process-oriented analysis in the context of construction techniques and level of safety risk. Moreover, designer with varying experiences of PtD tools such as BIM could provide better visualisation of structural, mechanical, electrical, or plumbing design elements and hence, improving hazard recognition performance (Hardison et al., 2020).

Another important experience is the construction site experience. It is well documented that designers lack the experience and practices required to address construction safety issues (Zhou et al., 2012; Oney-Yazici and Dulaimi, 2014). The fact that site operations are multidimensional (i.e. different trades, different roles and processes), understanding how risks and hazards can arise during construction and how they can be avoided or reduced through design requires someone familiar with the construction environment, safety regulations and risks around site activities, building materials and construction equipment. This is consistent with finding by Yuan et al. (2019) where integration of construction best practices together with safety knowledge could enhance the capability in identifying construction safety risks. For instance, such integration could provide solution to problems, such as types of cranes to be used, as well as the location of crane in confined construction sites (Sacks et al., 2015). Moreover, incorporating construction-related tasks and the risk management process could provide valuable input to the PtD decision-making process (Lyon et al., 2016). 
It is well documented that PtD is a collective ownership on eliminating hazards and minimising risks to workers and the end users. However, the traditional procurement method inhibits such collaboration due to complexity and fragmentation of the governance structure that limits designers' understanding on the constructability issues. Collaborative procurement is known to have the ability to solve such fragmentation through increased integration between all project entities and hence, allowing designers to influence construction safety (Tymvios and Gambatese, 2016). Experience in such environment could nurture the designers to work collaboratively (inter and intra-organisations), contributing to the expansion of their competence towards the improvement of construction processes and safety performance (Fonseca et al., 2014; Manu et al., 2019a). Such procurement also allows increased interaction and engagement between external stakeholders (that could influence design decisions in mega project), which could have significant OSH implications for construction workers (Lingard et al., 2012).

Experience in contract administration could increase the capability of designers on the implementation of PtD. The ability to understand contract terms, clauses related to PtD (i.e. regulate roles and responsibilities of designers, professional fees, etc.) could change the mindset and behaviour of designers and create a sense of responsibility towards OSH (Morrow et al., 2015; Karakhan and Gambatese, 2017). Such understanding could also lead to the commitment of the designers to OSH duties and their liability to PtD practices (Hare and Cameron, 2012).

One of the most cited barriers of $\mathrm{PtD}$ implementation is the lack of $\mathrm{PtD}$ education in tertiary education. Despite the fact that PtD is growingly being accepted in the construction industry of many countries, the PtD learning experience in tertiary education remains elusive (Behm et al., 2014; Lopez-Arquillos et al., 2015). The need to have education learning experience is critical to instil the motivation to address safety (Toole and Gambatese, 2008). 
Several challenges have been highlighted in the literature, namely due to congested curriculum structure (to incorporate related $\mathrm{PtD}$ subject) following the extensive requirements by accreditation bodies (especially for engineering programmes); lack of OSH priority from the industry; lack of experts at the institutions, lack of tools and resources and etc. (Cortes et al., 2012; Lopez-Arquillos et al., 2015). Nonetheless, several recommendations have been made to enhance the PtD learning experience in tertiary education. Apart from having specific PtD courses, the integration of diverse topics on PtD such as ethics, social sustainability, integrated design and construction, lifecycle analysis, and public policy can also be emphasised (Toole, 2017). Also, more innovative teaching and learning modes have been suggested, in particular through the use of pedagogical approaches; serious gaming and simulations; massive open online courses (MOOC) and lessons learned from real case studies (Din and Gibson, 2019; Che Ibrahim and Belayutham, 2020).

\section{Discussion}

The present study has identified a wide range of knowledge, skills and experience attributes that can be used to define designers' competency towards PtD practice. As these professional competencies are acquired, it is critical to ensure that these competency attributes are wellaligned with the key elements of $\mathrm{PtD}$ practices.

From the existing literatures, there are five main elements related to the PtD (see figure 2); (1) managing the risks by applying risk management approach and general principles of prevention; (2) appointing the right designer and organisations at the right time; (3) making sure everyone has the information, instruction, training and supervision they need to carry out their jobs in a way that secures safety and health; (4) designers cooperating and communicating with each other and coordinating their work; and (5) consulting workers and engaging with them to promote and develop effective measures to secure safety, health and welfare. 
The first key PtD element is the Risk Management Approach and Principles of Prevention. $\mathrm{PtD}$ is about preventing or minimising occupational hazards at early stages in the design process and the extensive reliance on tacit knowledge (construction, design, hazard and control measure) is inevitable as such knowledge will enable designers to fully integrate the reasonable and practical control measures. The use of wide-ranging risk analysis and information-enabled technologies combined with relevant practice experience will certainly ensure the efficiency and effectiveness of the PtD diffusion in dynamic construction lifecycle. In particular, the growing application of BIM enables the integration between design elements, constructability and safety requirements. This allows simulation and visualisation through the integration of multidisciplinary information for hazard identification caused by site characteristics and operations. Furthermore, ability to understand which hazards are recognisable in specific phases of design development and project delivery could provide key information for setting appropriate preventive measures (Hardison and Hallowell, 2019).

The second key PtD element is the appointment of the right person and organisation. The key attributes of knowledge, skills and experience is essential in defining a competent designer. It is stipulated in several PtD regulations (e.g. CDM Regulations 2015 in UK; DfS Regulation 2015 in Singapore) and associated guidelines (e.g. Occupational Safety and Health in Construction Industry (OSHCIM) in Malaysia) that designers who are seeking an appointment for design work should ensure they have the necessary skills, knowledge and experience to design a safe structure by taking into consideration the preventive practices. Having such attributes could ease the client into appointing the designers or the organisations at the right time, i.e. prior to the construction phase. As emphasised by Lyon et al. (2016), in order to be a successful designer, one has to take safety as a priority in the design by being proficient in the $\mathrm{PtD}$ concept, risk assessment and risk reduction methods related to 
construction. In addition, designers who are able to embrace innovation, particularly information technologies could further enhance their capability to undertake PtD practices.

It is well documented that $\mathrm{PtD}$ is about collective responsibility. This is in line with the third PtD element, which is the $3 C$ s (Cooperation, Communication and Coordination). The $3 C s$ cannot be easily materialised without the proper blend of competencies, such as skill (soft), experience (practical), and knowledge (explicit). Continuous and effective $3 \mathrm{Cs}$ is needed to ensure that every stakeholder understands (context and conditions) the potential risks and the possible control measures that can be taken. Greater owner-designer-constructor collaboration (e.g. in terms of co-location during design phase, spending more time on design phase, developing trusting relationships, using collaborative decision-making tools and sharing common financial incentives) can be very useful in facilitating effective PtD implementation (Gambatese, 2019). While traditional procurement inhibits such 3Cs, experience in managing projects based on collaborative procurement would give an added value (e.g. multi-party collaboration) in delivering the required $3 \mathrm{Cs}$ in ensuring the effectiveness of PtD practices. Procurement routes/methods such as design-build, integrated project delivery (IPD) and project alliance are potential project delivery methods for enabling effective PtD as they embrace the collaboration philosophy and enhance the designer's roles and responsibilities towards positive PtD attitude and practice.

The fourth element is the adequate information and instruction. It can be seen that in some of the related $\mathrm{PtD}$ legislations, such as $\mathrm{CDM}$ regulations, pre-construction information (including information on the site hazards) from the client to the designers and contractors is critical to enable both of the parties to fulfil their duties (Health and Safety Executive, 2015). Also a health and safety file (which is information about the completed structure that helps to manage future work (e.g. refurbishment or maintenance) in a safe and healthy manner) on the completed building/asset must be prepared (Health and Safety Executive, 2015). The need for 
designers to be able to act as information gatherers and communicators on project-related information is crucial to facilitate the development of PtD activities. Providing such information and instruction require certain skills, knowledge and experience, especially when dealing with dynamic environments in project lifecycle. For instance, having capabilities associated with technologies is vital to improve safety, especially during periods of rapid design changes (Larsen and Whyte, 2013). Such capabilities could also influence design decisions in different stages of a facility (Lingard et al., 2013).The fifth element, engagement or consultation with workers in regards to OSH is a common legal OSH requirement that requires predominantly the social skill with explicit knowledge. The study by Wachter and Yorio (2014) indicated that engagement with workers associates designers as mediators between safety management practices and the safety performance. The lack of engagement among the designers could inhibit the total diffusion in PtD practice. This is supported by Webster (2013), where having direct and indirect continuous interaction with workers helps to motivate the workforce towards achieving the desired safety goals. The engagement is a twoway process by providing required information (e.g. risk and hazards, control measures, etc.), sharing best practices, listening to their opinion and making collective decisions. This practice will ensure holistic approach being implemented by incorporating on site / hands-on experience towards preventing hazards, as well as increasing the level of commitment as every party would know their roles and responsibilities.

In summary, the success in the implementation of PtD is built upon the elements of $\mathrm{PtD}$, which cannot be materialised without the attributes of $\mathrm{PtD}$ knowledge, skill and experience among the designers. Having such competency attributes would enable designers to adequately consider workers' health and safety while designing built assets. The right competency attributes that supports these PtD elements are critical as designers' credential in 
knowledge, advancements of skills and real-life experience is the key for conceptualising and creating buildings or structures that minimises or eliminates risk at its core.

\section{Implication for practice}

This study also offers a number of practical implications for the designers, design organisations and the policy makers within the construction industry. Firstly, the results, in particular the competency attributes could act as a point of reference for designers or design organisations to self-examine their PtD capability and hence adapt to a situation where continuous improvement of capability development is significant towards responding to the established PtD policies or associated guidelines.

Secondly, the identification of the competency attributes act as an entry point and a significant interface between designers and key stakeholders in achieving high level of collaboration; hence minimising fragmentation in the construction industry and thereby encouraging greater productivity in the construction sector.

Thirdly, the competency attributes could be used as part of a client's pre-qualification arrangements (client legal duty on OSH, in particular countries with OSH requirements in the procurement process) in selecting firms that have designers with the required PtD competency.

Fourthly, the key competency attributes could provide an added value to the existing $\mathrm{PtD}$ regulations and/or their associated codes of practice or guidance documents by incorporating the attributes into such regulations and/or their associated codes of practice or guidance. This would give clearer guidance to industry stakeholders regarding the constituents of designers' PtD competency.

Finally, with the increasing number of future architectural and engineering designer graduates from higher educational institutions, the competency attributes could guide the curricula development (assisted by professional bodies) for architectural and engineering 
programs as well as the content of continuing professional development courses to support the continuity of lifelong PtD learning.

\section{Conclusions}

In recent years, great emphasis has been made on the importance of designers' competencies to $\mathrm{PtD}$ practices in the construction industry. This study is a step forward from the current efforts in understanding the competency attributes required by designers in order to be able to implement $\mathrm{PtD}$ practices. In order to achieve this aim, 88 relevant $\mathrm{PtD}$ studies published in peer-reviewed construction journals were aggregated and systematically reviewed. From the review, $18 \mathrm{PtD}$ key competency attributes were identified and categorised under three main categories as follows; tacit (i.e. construction, design feature, hazard and control measures) and explicit (i.e. management concepts, contract / procurement, OSH \& PtD legislative and associated guidelines) knowledge; technical (i.e. hazard recognition skills, hazard and risk analysis, information technology enabled tools, financial analysis / cost-benefit analysis) and soft (i.e. collaboration) skills; and experience (i.e. design, dynamic of the design and construction process, $\mathrm{PtD}$ activities / process / tools, construction site, collaborative project delivery, managing contract documents, PtD learning). Additionally, a framework indicating key $\mathrm{PtD}$ elements and their relation to the $18 \mathrm{PtD}$ competency attributes has been developed. The key attributes summarised in this paper have general applicability for both designers and researchers in construction, who are seeking for a useful reference in pursuing for professional PtD competencies. The findings from this study has provided a valuable platform for designers to further instil and embrace the prevention culture (e.g. reducing OSH risk at work site) through design activities, subsequently stimulating better safety performance. In addition, the study highlights that by creating collective and collaborative oriented practices, innovative solutions to mitigate OSH hazards through design decisions could be achieved. Despite the 
objectives of this study have been achieved, conclusions from the research should be drawn in the light of some limitations. First, the PtD competency attributes in this study is limited to the construction context, and hence limiting the generalizability of the findings to other industries. Secondly, this study was also limited mainly to designers involved in construction projects.

\section{Future direction}

The consolidated set of key PtD competency attributes derived from this paper lays a solid foundation for further developments including the development of a competency index for designers' competency in construction projects. The resulting index could serve as a robust process improvement tool to enable designers to monitor, measure and improve their PtD competency level. The index could also provide a mechanism to ascertain the PtD capability of organisations under the relevant OSH regulations.

\section{Acknowledgement}

The work described in this paper was fully supported by a research grant from the National Institute of Occupational Safety and Health (NIOSH), Malaysia (Ref No. 0316/03/DCM.2020/01). Its contents are solely the responsibility of the authors and do not necessarily represent the official views of the NIOSH.

\section{References}

Abueisheh, Q., Manu, P., Mahamadu, A.-M., and Cheung, C. (2020), "Design for safety implementation among design professionals in construction: The context of Palestine", Safety Science, Vol. 128, 104742.

Addis, M. (2016), "Tacit and explicit knowledge in construction management", Construction management and Economics, Vol. 34 No. 7-8, pp. 439-445.

Behm, M (2005), "Linking construction fatalities to the design for construction safety concept", Safety Science, Vol. 43 No. 8, pp. 589-611. 
Behm, M J, Culvenor, J and Dixon, G (2014), "Development of safe design thinking among engineering students", Safety Science, Vol. 63, pp. 1-7.

Bong, S., Rameezdeen, R., Zuo, J., Man Li, R. Y., and Ye, G. (2015), “The designer's role in workplace health and safety in the construction industry: Post-harmonized regulations in South Australia”, International Journal of Construction Management, Vol. 15 No. 4, pp. 276-287.

Che Ibrahim, C K I and Belayutham, S. (2020), “A Knowledge, Attitude and Practices (KAP) Study on Prevention through Design: A Dynamic insight into Civil and Structural Engineers in Malaysia", Architectural Engineering and Design Management, Vol. 16 No. 2, pp. 131-149.

Cortes, J. M., Pellicer, E. and Catala, J. (2012), "Integration of occupational risk prevention courses in engineering degrees: Delphi study", Journal of Professional Issues in Engineering Education \& Practice, Vol. 138 No. 1, pp. 31-36.

Darko, A. and Chan, A. P. C. (2016), "Critical analysis of green building research trend in construction journals", Habitat International, Vol. 57, pp. 53-63.

Department of Occupational Safety and Health (DOSH) (2020), "Guidelines of Occupational Safety and Health in Construction Industry (Management) 2017”, available at https://www.dosh.gov.my/index.php/factory-machinery/eparticipation/2350-guidelinesof-occupational-safety-and-health-in-construction-industry-management-2017/file (accessed 26 March 2020).

Dewlaney, K.S and Hallowell, M. (2012), "Prevention through design and construction safety management strategies for high performance sustainable building construction", Construction Management and Economics, Vol. 30, pp. 165-177.

Dharmapalan, V., Gambatese, J. A., Fradella, J. and Vahed, A. M. (2015), “Quantification and Assessment of Safety Risk in the Design of Multi-storey Buildings, Journal of Construction Engineering and Management, Vol. 141 No. 4, 04014090.

Din, Z. U. and Gibson, E. (2019), "Serious games for learning prevention through design concepts: An experimental study”, Safety Science, Vol. 115, pp. 176-187.

Driscoll, T. R., Harrison, J. E., Bradley, C., and Newson, R. S. (2008), “The role of design issues in work- related fatal injury in Australia”, Journal of Safety Research, Vol. 39 No. 2, pp. 209-214. 
Edirisinghe, R, Stranieri, A and Blismas, N (2016), "Information visualisation for the wicked problem of safe construction design", Architectural Engineering and Design Management, Vol. 12 No. 4, pp. 296-310.

Elias, I., Felix, H. David, P. and David, O. (2011), "Improving Construction Health and Safety: Application of Cost-Benefit Analysis (CBA) for Accident Prevention", International Journal of Construction Management, Vol. 11 No.1, pp. 19-35.

Ezisi, U. and Issa and M. H. (2018), "Case Study Application of Prevention through Design to Enhance Workplace Safety and Health in Manitoba Heavy Construction Projects", Canadian Journal of Civil Engineering, Vol. 46 No. 9, pp. 124-133.

Fellows, R.F. and Liu, A.M.M. (2015), "Research Methods for Construction”, 4th ed., John Wiley \& Sons, West Sussex.

Fonseca, E. D., Lima, F. P. A. and Duarte, F. (2014), "From construction site to design: The different accident prevention levels in the building industry", Safety Science, Vol. 70, pp. 406-418.

Gambatese, J. (2019), "Prevention Through Design (PtD) in the project delivery process: A PtD Sourcebook for Construction Site Safety”, Oregon State University. Retrieved from https://designforconstructionsafety.files.wordpress.com/2019/09/ptd-in-the-projectdelivery-process.pdf

Gambatese, J. A., Behm, M. and Hinze, J. (2005), "Viability of Designing for Construction Worker Safety”, Journal of Construction Engineering and Management, Vol. 131 No. 9, 1029-1036.

Gambatese, J. A., Gibb, A. G., Brace, C., and Tymvios, N. (2017), "Motivation for Prevention through design: Experiential perspectives and practice, Special collection on construction safety”. Practice Periodical on Structural Design and Construction, Vol. 22 No. 4, 04017017.

Gangolells, M., Casals, M., Forcada, N., Roca, X. and Fuertes, A. (2010), "Mitigating construction safety risks using prevention through design", Journal of Safety Research, Vol. 41 (2010), pp.107-122

Goh, Y. M., and Chua, S. (2016), "Knowledge, attitude and practices for design for safety: A study on civil \& structural engineers", Accident Analysis and Prevention, Vol. 93, pp. 260-266. 
Hadikusumo, B. H. W. and Rowlinson, S. (2004), "Capturing Safety Knowledge Using Designfor-Safety-Process Tool”, Journal of Construction Engineering and Management, Vol. 130 No. 2, pp. 281-289.

Hallowell, M and Hardison D (2019), “Construction hazard prevention through design: Review of perspectives, evidence, and future objective research agenda", Safety Science, Vol. 120, pp. 517-526.

Hallowell, M. R. and Hansen, D. (2016), "Measuring and improving designer hazard recognition skill: Critical competency to enable prevention through design”, Safety Science, Vol. 82, pp. 254-263.

Hardison and Hallowell (2019), "Construction hazard prevention through design: Review of perspectives, evidence, and future objective research agenda”, Safety Science, Vol. 120, pp. 517-526.

Hardison D., Hallowell M., Littlejohn R. (2020), "Does the format of design information affect hazard recognition performance in construction hazard prevention through design reviews?”, Safety Science, Vol. 121, pp. 191-200.

Hare, B. and Cameron, I. (2012), "Health and safety gateways for construction projects planning”, Engineering, Construction and Architectural Management, Vol. 19 No. 2, pp. 192-204.

Haslam, R.A., Hide, S.A., Gibb, A.G.F., Gyi, D.E., Pavitt, T., Atkinson, S., Duff, A.R. (2005), "Contributing factors in construction accidents", Applied Ergonomics, Vol. 36, pp. 401415

Hayne, G., Kumar, B. and Hare, B. (2017), "Design hazard identification and the link to site experience", Proceedings of the ICE - Management, Procurement and Law, Vol. 170 No. 2, pp. 85-94.

Hinze, J and Wiegand, F. (1992),'Role of Designers in Construction Worker Safety", Journal of Construction Engineering and Management, Vol. 118 No.4, pp. 667-684.

Ho, C. Lee, H. W. and Gambatese, J. A. (2020), “Application of Prevention through Design $(\mathrm{PtD})$ to improve the safety of solar installations on small buildings", Safety Science, Vol. 125, 104633. 
HSE (2015), "Managing health and safety in construction - Construction (Design and Management) Regulations 2015”, Guidance L153. HSE Books: Norwich.

Hui, T. T. (2015), “Accidents that can be prevented through design and examples of DfS. DFS Forum”, $21 \quad$ Oct $2015 . \quad$ Retrieved from https://www.wshc.sg/files/wshc/upload/event/file/4_DfS_examples.pdf

Ibrahim, K. I., Costello, S. B. and Wilkinson, S. (2013), "Key practice indicators of team integration in construction projects: a review", Team Performance Management, Vol. 19 No. 3/4, pp. 132-152.

Jin, Z., Gambatese, J., Liu, D. and Dharmapalan, V. (2019), "Using 4D BIM to assess construction risks during the design phase", Engineering, Construction and Architectural Management, Vol. 26 No. 11, pp. 2637-2654.

Karakhan, A. A., and Gambatese, J. A. (2017), "Integrating worker health and safety into Sustainable design and construction: Designer and constructor perspectives", Journal of Construction Engineering and Management, Vol. 143 No. 9, 04017069.

Krippendorff, K. (2013), “Content Analysis. An Introduction to Its Methodology”, (3rd ed). California, CA: Sage Publications.

Labagnara D., Maida L. and Patrucco M. (2015), "Firedamp explosion during tunneling operations: Suggestions for a prevention through design approach from case histories", Chemical Engineering Transactions, Vol. 43, pp. 2077-2082.

Larsen, G. D., and Whyte, J. (2013), "Safe construction through design: Perspectives from the site team, Construction Management and Economics”, Vol. 31 No. 6, pp. 675-690.

Li, Y., Lu, Y. and Cui, Q. and Han, Y. (2019), “Organisational Behavior in Megaprojects: Integrative Review and Directions for Future Research", Journal of Management in Engineering, Vol. 35 No. 4, 04019009.

Lingard, H., Saunders, L., Pirzadeh, P., Blismas, N., Kleiner, B. and Wakefield, R. (2015), "The relationship between pre-construction decision-making and the effectiveness of risk control: Testing the time-safety influence curve", Engineering, Construction and Architectural Management, Vol. 22 No. 1, pp. 108-124. 
Lingard, H., Warmerdam, A. and Shooshtarian, S. (2019), "Getting the balance right: Regulating occupational health and safety planning and coordination in the Australian construction industry", Engineering, Construction and Architectural Management, Vol. 26 No. 3, pp. 599-617.

López-Arquillos, Rubio-Romero, J C and Martinez-Aires, M D (2015), "Prevention through Design (PtD), The importance of the concept in Engineering and Architecture university courses", Safety Science, Vol. 73, pp. 8-14.

Lyon, B. K., Popov, G., and Biddle, E. (2016), "Prevention through design: For hazards in construction”, Professional Safety, Vol. 61 No. 9, pp. 37-44.

Manu, P, Mahdjoubi, Gibb and Behm (2017), "New tool will help civil engineers meet CDM requirements to design for safety", Civil Engineering, Vol. 170, CE2, 55.

Manu, P, Poghosyan, A, Mahamadu, A, Mahdjoubi, L, Gibb, A, Behm, M and Akinade, O (2019), "Design for occupational safety and health: key attributes for organisational capability", Engineering, Construction and Architectural Management, Vol. 26 No. 11, pp. 2614-2636.

Manu, P, Gibb, A., Drake, C., Jones, W., Bust, P., Mahamadu, A-M. and Behm, M. (2019b), "Skills-Knowledge-Attitude-Training-Experience (SKATE) in 'Designing for Occupational Health of Construction Workers", SKATE final report February 2019, B\&CE Charitable Trust, pp. 1-13.

Manu, P. A., Ankrah, N. A., Proverbs, D. G. and Suresh, S. (2012), "Investigating the multicausal and complex nature of the accident causal influence of construction project features", Accident Analysis and Prevention, Vol. 48, pp. 126-133.

Manu, P., Ankrah, N., Proverbs, D., and Suresh, S. (2014), "The health and safety impact of construction project features", Engineering, Construction and Architectural Management, Vol. 21 No. 1, pp. 65-93.

Manu, P., Poghosyan, A. M., Agyei, G., Mahamadu, A. M. and Dziekonski, K. (2018), "Design for safety in construction in sub- Saharan Africa: A study of architects in Ghana", International Journal of Construction Management, doi:10.1080/ 15623599.2018.1541704 
Morrow, S, Cameron, I, and Hare, B (2015), "The effects of framing on the development of the design engineer: Framing health and safety in design", Architectural Engineering and Design Management, Vol. 11 No. 5, pp. 338-359.

Mzyece, D., Ndekugri, I. and Ankrah, N. (2019), "Building information modelling (BIM) and the CDM regulations interoperability framework", Engineering, Construction and Architectural Management, Vol. 26 No. 11, pp. 2682-2704.

Narbaev, T. De Marco, A. and Orazalin, N. (2019), "A multidisciplinary meta-review of the public-private partnerships research", Construction Management and Economics, Vol. 38 No. 2, pp. 109-125

Okpala, I., Nnaji, C. and Karakhan, A. A. (2020), "Utilizing Emerging Technologies for Construction Safety Risk Mitigation”, Pract. Period. Struct. Des. Constr., Vol. 25 No. 2 , 04020002.

Oney-Yazici, E., \& Dulaimi, M. F. (2015), “Understanding designing for construction safety: The interaction between confidence and attitude of designers and safety culture", Architectural Engineering and Design Management, Vol. 11 No. 5, pp. 325-337

Osei-Kyei, R. and Chan, A. P. C. (2005), "Review of studies on the Critical Success Factors for Public-Private Partnership (PPP) projects from 1990 to 2013”, International Journal of Project Management, Vol. 33 No. 6, pp. 1335-1346.

Poghosyana, A, Manu P, Mahamadu, A M, Akinade, O, Mahdjoubi, L, Gibb, A and Behm, M (2020), "A web-based design for occupational safety and health capability maturity indicator", Safety Science, Vol. 122, 104516.

Popov, G, Blunt, L A, McGlothlin, J, Young-CorbeJ, D, Zey, J N and Heckel, P (2013), "Education: Integrating PTD into Undergraduate Curricula", Professional Safety, 2013(3), pp. 45-49.

Qi, J., Issa R.R.A., Olbina S., Hinze J. (2014), "Use of building information modeling in design to prevent construction worker falls", Journal of Computing in Civil Engineering, Vol. 28 No. 5, A4014008

Quinn, R., Faerman, S., Thompson, M and McGrath, M (1996), "Becoming A Master Manager: A Competency Framework", second edition, John Wiley and Sons, USA. 
Rajendran, S. and J. Gambatese (2013), "Risk and financial impacts of prevention through design solutions", Practice Periodical on Structural Design and Construction, Vol. 18 No.1, pp. 67-72.

Raouf, A. M. I. and Al-Ghamdi, S. G. (2019), "Effectiveness of Project Delivery Systems in Executing Green Buildings", Journal of Construction Engineering and Management, Vol. 145 No.10, 03119005.

Sacks, R., Whyte, J., Swissa, D., Raviv, G., Zhou, W. and Shapira, A. (2015), "Safety by design: Dialogues between designers and builders using virtual reality", Construction Management and Economics, Vol. 33 No.1, pp. 55-72.

Sherratt, F. and Ivory, C (2019), “Managing 'A Little Bit Unsafe': Complexity, Construction Safety and Situational Self-Organising", Engineering, Construction and Architectural Management, Vol. 26 No.11, pp. 2519-2534.

Siraj, N. B. and Fayek, A. R. (2019), "Risk Identification and Common Risks in Construction: Literature Review and Content Analysis”, Journal of Construction Engineering and Management, Vol. 145 No. 9, 03119004.

Szymberski, R (1997), "Construction project safety planning", Technical Association of the Pulp and Paper Industry (TAPPI) Journal, Vol. 80 No.11, pp. 69-74.

Teo, A.L.E., Ofori G., Tjandra I.K. and Kim H.(2016), "Design for safety: Theoretical framework of the safety aspect of BIM system to determine the safety index", Construction Economics and Building, Vol. 16 No.4, pp. 1-18.

Toh, Y Z, Goh, Y M and Guo, B H W (2017) "Knowledge, Attitude, and Practice of Design for Safety: Multiple Stakeholders in the Singapore Construction Industry", Journal of Construction Engineering and Management, Vol. 143 No. 5, 04016131.

Toole, T. M. and J. Gambatese (2008) "The trajectories of Prevention through Design in construction", J Safety Res, Vol. 39 No. 2, pp. 225-230.

Toole M. (2017), “Adding Prevention through Design to Civil Engineering Educational Programs", Journal of Professional Engineering Education and Practice, Vol. 143 No. 4, 02517005 .

Toole, M., Gambatese, J. A. and Abowitz, D. A. (2017), “Owners' Role in Facilitating Prevention through Design", Journal of Professional Issues in Engineering Education and Practice, Vol. 143 No.1, 04016012. 
Toole, T. M. (2005), “Increasing engineers' role in construction safety: opportunities and barriers", Journal of Professional Issues in Engineering Education and Practice, Vol. 131 No. 3, pp. 199-207.

Toole, T. M. and Erger, K. (2019), "Prevention through Design: Promising or Perilous?", Journal of Legal Affairs and Dispute Resolution in Engineering and Construction, Vol. 11 No. 1, 04518023.

Tymvios, N. and Gambatese, J. A. (2016), "Perceptions about Design for Construction Worker Safety: Viewpoints from Contractors, Designers, and University Facility Owners", Journal of Construction Engineering and Management, Vol. 142 No. 2, 04015078

Wachter, J. K. and Yorio, P. L. (2014), “A system of safety management practices and worker engagement for reducing and preventing accidents: an empirical and theoretical investigation", Accid Anal Prev, Vol. 68, pp. 117-30.

Webster, M. (2013), “The use of CDM 2007 in the London 2012 construction programme", Proceedings of the Institution of Civil Engineers - Civil Engineering, Vol. 166 No. 1, pp. $35-41$.

Weidman, J., Dickerson. D. E. and Koebel, C. T. (2015), "Prevention through design adoption readiness model (PtD ARM): An integrated conceptual model”, Work, Vol. 52 No. 4, pp. 865-876.

Wilbanks, D. W. (2015), "Prevention Through Design: A Curriculum Model to Facilitate Hazard Analysis \& Risk Assessment”, Professional Safety, April 2015, pp.46-51.

Xiahou, X, Yuan, J, Li, Q and Skibniewski, M J (2018), "Validating DFS concept in lifecycle subway projects in China based on incident case analysis and network analysis", Journal of Civil Engineering and Management, 24(1), 53-66.

Yi, H. and Yang, J. (2014), "Research trends of post disaster reconstruction: The past and the future", Habitat International, Vol. 42, pp. 21-29.

Yibo Y., Xiahou, X. and Li, Q. (2020), "Critical Factors of Promoting Design for Safety in China's Subway Engineering Industry”, Int. J. Environ. Res. Public Health, Vol. 17, 3373. 
Yuan J., Li X., Xiahou X., Tymvios N., Zhou Z. and Li Q. (2019), “Accident prevention through design $(\mathrm{PtD})$ : Integration of building information modeling and $\mathrm{PtD}$ knowledge base”, Automation in Construction, Vol. 102, pp. 86-104. Zhao, D., McCoy A.P., Kleiner B.M. and Smith-Jackson T.L. (2015), "Overview and analysis of safety management studies in the construction industry", Safety Science, Vol. 72, pp. 337 - 350. 


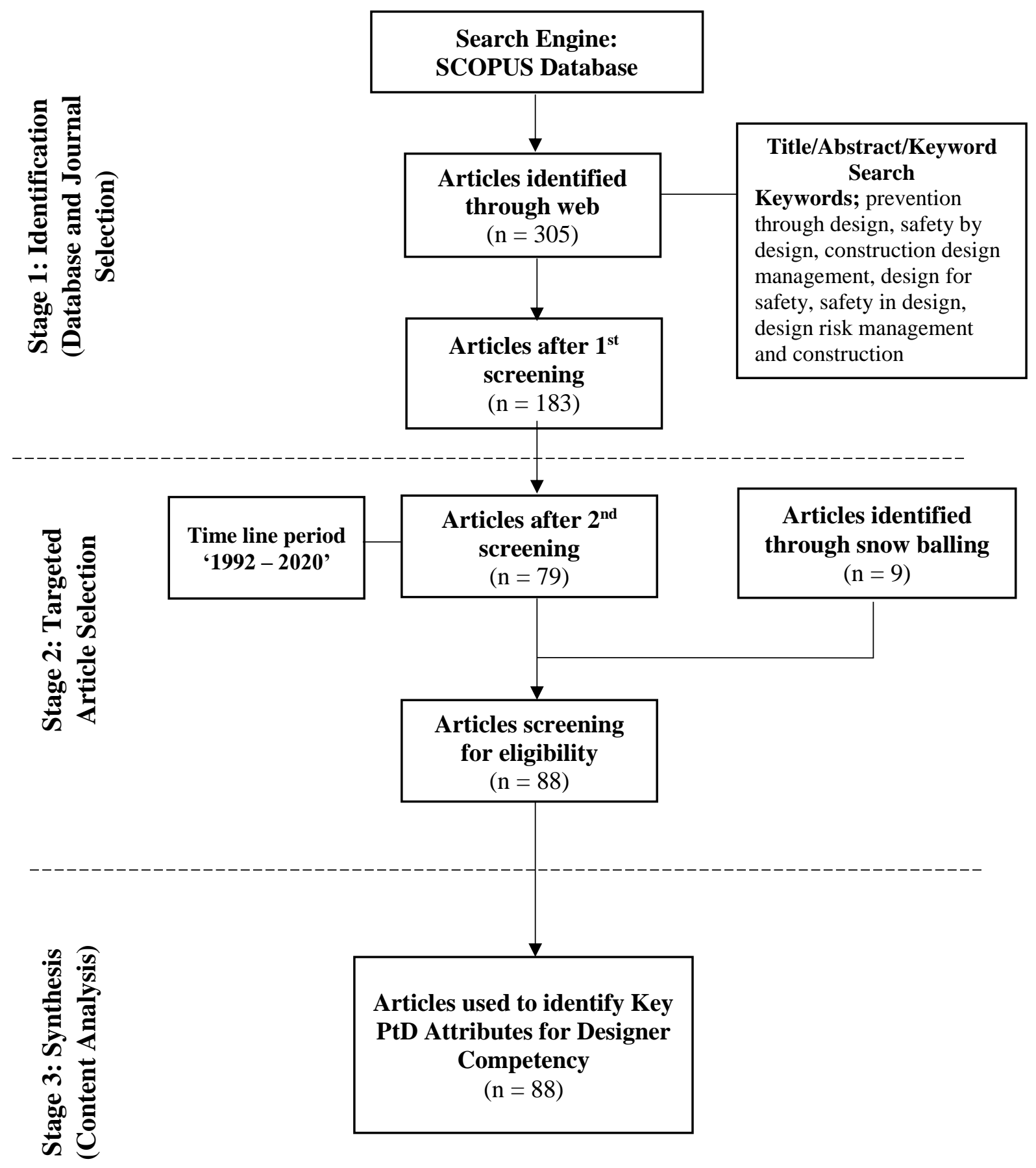

Figure 1: Research methodology for the systematic review 


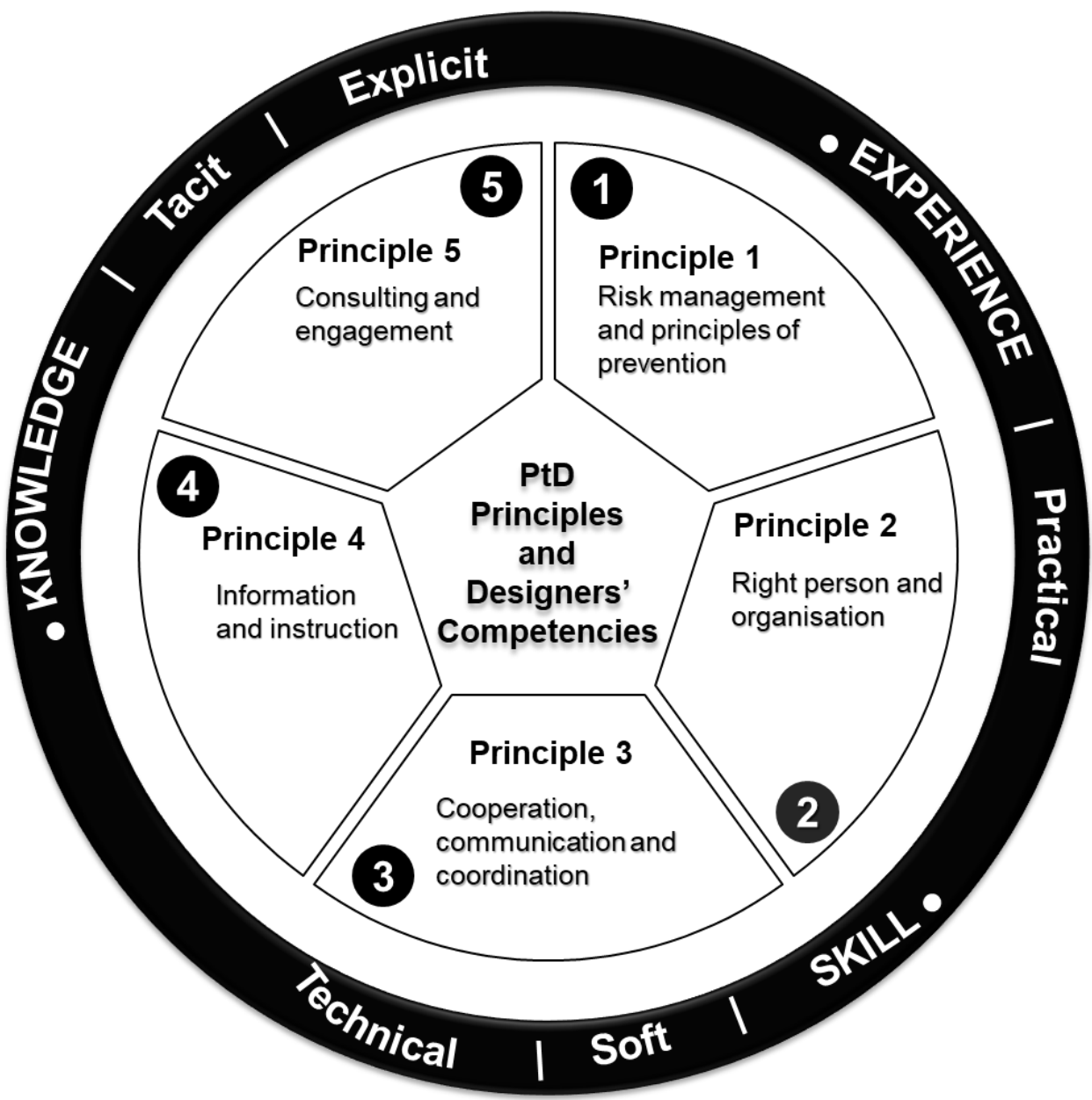

Figure 2: The PtD elements and attributes of designer's competencies framework 
Table 1: Distribution of articles per journal / proceeding in Stage 1

\begin{tabular}{|c|c|c|}
\hline Type & Journal Name & Frequency \\
\hline \multirow{15}{*}{ Journal } & Safety Science & 17 \\
\hline & Journal of Construction Engineering and Management & 16 \\
\hline & Automation in Construction & 8 \\
\hline & Construction Management and Economics & 7 \\
\hline & $\begin{array}{l}\text { Proceedings of the Institution of Civil Engineers: Civil } \\
\text { Engineering }\end{array}$ & 6 \\
\hline & Engineering, Construction and Architectural Management & 5 \\
\hline & Journal of Safety Research & 5 \\
\hline & Architectural Engineering and Design Management & 3 \\
\hline & $\begin{array}{l}\text { Proceedings of Institution of Civil Engineers: Management, } \\
\text { Procurement and Law }\end{array}$ & 3 \\
\hline & Practice Periodical on Structural Design and Construction & 3 \\
\hline & Building Engineer & 3 \\
\hline & International Journal of Construction Management & 2 \\
\hline & Journal of Architectural Engineering & 2 \\
\hline & $\begin{array}{l}\text { Journal of Professional Issues in Engineering Education and } \\
\text { Practice }\end{array}$ & 2 \\
\hline & $\begin{array}{l}\text { Others*: Construction Economics and Building, Built } \\
\text { Environment Project and Asset Management, Buildings, etc. }\end{array}$ & 56 \\
\hline \multirow[t]{4}{*}{ Proceeding } & $\begin{array}{l}\text { Association of Researchers in Construction Management } \\
\text { (ARCOM) }\end{array}$ & 8 \\
\hline & ASSE Professional Development Conference and Exposition & 5 \\
\hline & Construction Research Congress & 4 \\
\hline & $\begin{array}{l}\text { Others }{ }^{\wedge} \text { : Procedia Engineering, IOP Conference Series: } \\
\text { Materials Science and Engineering, International Conference } \\
\text { on Construction and Real Estate Management, etc. }\end{array}$ & 28 \\
\hline
\end{tabular}

Note: *one article per journal; ^ $\max$. of 2 two articles per proceeding 
Table 2: Glossary of terms and its definition used in the designer's competency framework

Term Study Definition

Capability Designer's ability to explicitly consider OSH in their design decisions in order to protect the OSH of builders and maintenance workers

Competency Possession of knowledge, skills and experience by the designer to perform PtD practices

Competency Attributes or aspects of the relevant knowledge, skills and experience attributes required by designers to perform $\mathrm{PtD}$ practices.

Knowledge The practical or theoretical understanding of a relevant PtD subject

Skills Learned proficiencies to smoothly and adaptively carryout activities or job functions related to PtD.

Experience A direct involvement, observation of or practical acquaintance in related events in a related PtD subject. 
Table 3: The Distribution of the Key Attributes on Knowledge, Skills and Experience

\begin{tabular}{|c|c|c|c|c|}
\hline Main & Sub & Key Attributes & Examples / Descriptions of attributes & Relevant Authors (Examples) \\
\hline Knowledge & Tacit & Construction & $\begin{array}{l}\text { The designer demonstrates his/her familiarity with } \\
\text { the understanding of a broad range of construction } \\
\text { knowledge including but not limited to: } \\
\text { - Construction methodology: in-situ and off-site } \\
\text { production; sequencing; work level; component } \\
\text { scale, location of installation } \\
\text { - Site characteristic (site location \& surroundings) - } \\
\text { Wind; Environmental Building features; } \\
\text { transportability; } \\
\text { - Construction site layout issues, such as terrain, } \\
\text { site logistics, electrical power and construction } \\
\text { equipment operation }\end{array}$ & $\begin{array}{l}\text { Toole (2005); Hare and Cameron } \\
\text { (2012); Dewlaney and Hallowell. } \\
\text { (2012); Larsen and Whyte (2013); } \\
\text { Edirisinghe et al. (2016); }\end{array}$ \\
\hline & Tacit & Design feature & $\begin{array}{l}\text { The designer demonstrates his/her familiarity with } \\
\text { the understanding of a broad range of knowledge on } \\
\text { design features including but not limited to; } \\
\text { - Design element; Mitigation narrative } \\
\text { - Peculiar design } \\
\text { - Parameter constraint (Physical, material property } \\
\text { set) } \\
\text { - Functional constrain (accessibility) } \\
\text { - Topological constrain } \\
\text { - Mechanical, Electrical and Plumbing (MEP) } \\
\text { system }\end{array}$ & $\begin{array}{l}\text { Toole (2005); Dharmapalan et al. } \\
\text { (2015); Edirisinghe et al. (2016); } \\
\text { Hardison et al. (2020) }\end{array}$ \\
\hline
\end{tabular}




\begin{tabular}{|c|c|c|c|}
\hline Tacit & $\begin{array}{l}\text { Hazard and } \\
\text { control measures }\end{array}$ & $\begin{array}{l}\text { The designer demonstrates his/her familiarity with } \\
\text { the understanding of a broad range of knowledge on } \\
\text { hazard and control measures including but not } \\
\text { limited to; } \\
\text { - Latent Hazard: Design hazard } \\
\text { - Patent Hazard: Construction hazard; Maintenance } \\
\text { and operation hazard, Spatial hazard, Electrical } \\
\text { hazard } \\
\text { - Control measures (i.e. elimination, substitution, } \\
\text { engineering controls, administrative controls and } \\
\text { personal protective equipment). }\end{array}$ & $\begin{array}{l}\text { Hayne et al. (2017); Hallowell and } \\
\text { Hansen (2016); Zhao et al. (2015) }\end{array}$ \\
\hline Explicit & $\begin{array}{l}\text { Management } \\
\text { concepts }\end{array}$ & $\begin{array}{l}\text { The designer demonstrates his/her familiarity with } \\
\text { the understanding of a broad range of knowledge on } \\
\text { management concepts including but not limited to; } \\
\text { - PtD principles; Professional Ethics; } \\
\text { Sustainability; Integrated design and } \\
\text { construction; Life cycle analysis }\end{array}$ & $\begin{array}{l}\text { Toole (2017); Karakhan and } \\
\text { Gambatese (2017); Gambatese et } \\
\text { al. (2017) }\end{array}$ \\
\hline Explicit & $\begin{array}{l}\text { Contract } \\
\text { procurement }\end{array}$ & $\begin{array}{l}\text { The designer demonstrates his/her familiarity with } \\
\text { the understanding of a broad range of } \\
\text { contract/procurement knowledge including but not } \\
\text { limited to; } \\
\text { - Collaborative procurement (e.g. Integrated } \\
\text { Project Delivery (IPD), partnering, alliance, early } \\
\text { contractor involvement (ECI) }\end{array}$ & $\begin{array}{l}\text { Toole (2005); Gambatese et al. } \\
\text { (2005); Hinze and Wiegand } \\
\text { (1992); Bong et al. (2015); Toole } \\
\text { and Erger (2019); Che Ibrahim } \\
\text { and Belayutham (2020); }\end{array}$ \\
\hline
\end{tabular}


- Contract: Liability, indemnification clauses, construction observation requirements, and dispute resolution methods.

\begin{tabular}{|c|c|c|c|c|}
\hline Explicit & $\begin{array}{l}\text { OSH and } \\
\text { legislative } \\
\text { guidelines }\end{array}$ & $\begin{array}{r}\mathrm{PtD} \\
/\end{array}$ & $\begin{array}{l}\text { The designer demonstrates his/her familiarity with } \\
\text { the understanding of a broad range of knowledge on } \\
\text { related OSH and PtD legislative / guidelines } \\
\text { including but not limited to; }\end{array}$ & $\begin{array}{l}\text { Webster (2013); Mzyece et al. } \\
\text { (2019); Lingard et al. (2019); Yue } \\
\text { et al. (2020) }\end{array}$ \\
\hline
\end{tabular}

- OSH and PtD legislative framework such as CDM, Workplace Health and Safety (WHS), OSHCI(M) guideline, industry codes of practice

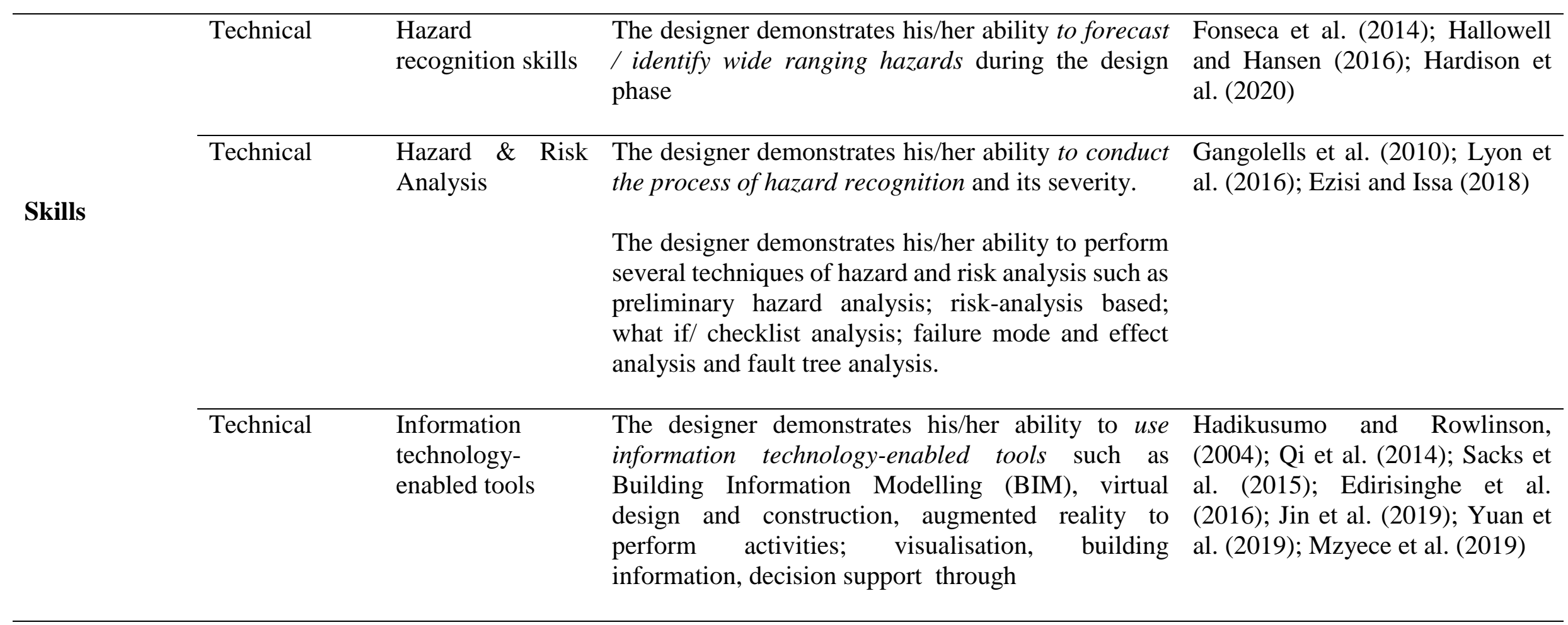




\begin{tabular}{|c|c|c|c|c|}
\hline & Technical & $\begin{array}{l}\text { Financial analysis } \\
/ \quad \text { cost-benefit } \\
\text { analysis }\end{array}$ & $\begin{array}{l}\text { The designer demonstrates his/her ability to perform } \\
\text { cost-benefit analysis in order to justify PtD design } \\
\text { expenditures in the early design phase }\end{array}$ & $\begin{array}{l}\text { Toole (2005); Rajendran and } \\
\text { Gambatese (2013); Dharmapalan } \\
\text { et al. (2015); Tymvios and } \\
\text { Gambatese (2016); Lingard et al., } \\
2019\end{array}$ \\
\hline & Soft & Collaboration & $\begin{array}{l}\text { The designer demonstrates his/her ability to work } \\
\text { collaboratively (possessing the collaborative } \\
\text { attributes; e.g. communication, trust, leadership, } \\
\text { teamwork) with other professionals towards } \mathrm{PtD} \\
\text { practices. }\end{array}$ & $\begin{array}{l}\text { Webster (2013); Morrow et al. } \\
\text { (2015); Weidman et al. (2015); } \\
\text { Toole et al. (2017); Manu et al. } \\
\text { (2019); Poghosyan et al. (2020) }\end{array}$ \\
\hline & & $\begin{array}{l}\text { Design } \\
\text { experience }\end{array}$ & $\begin{array}{l}\text { The designer have the experience of doing design } \\
\text { works (manual or digital) related to real-life } \\
\text { construction projects }\end{array}$ & $\begin{array}{l}\text { Lingard et al. (2013); Larsen and } \\
\text { Whyte (2013); Hardison et al. } \\
\text { (2020) }\end{array}$ \\
\hline \multirow{2}{*}{ Experience } & & $\begin{array}{l}\text { Dynamic of the } \\
\text { design process \& } \\
\text { construction } \\
\text { practice }\end{array}$ & $\begin{array}{l}\text { The designer have the experience working in different } \\
\text { types of facility / projects with different scale of } \\
\text { complexity. }\end{array}$ & $\begin{array}{l}\text { Gambatese et al. (2005); Larsen } \\
\text { and Whyte (2013); Xiahou et al. } \\
\text { (2018) }\end{array}$ \\
\hline & & Construction site & $\begin{array}{l}\text { The designer have the working experience at } \\
\text { construction site - Involvement in wide range of } \\
\text { construction site operations (e.g. mobilizing } \\
\text { machinery and equipments, constructing, altering, } \\
\text { repairing, extending or demolishing of buildings or } \\
\text { structures works) }\end{array}$ & $\begin{array}{l}\text { Larsen and Whyte (2013); } \\
\text { Fonseca et al. (2014); Oney- } \\
\text { Yazici and Dulaimi (2014); Sacks } \\
\text { et al., 2015; Hayne et al. (2017) }\end{array}$ \\
\hline
\end{tabular}


Collaborative project delivery
The designer have the working experience in $a$ Tymvios and Gambatese (2016); collaborative project delivery model that integrates people, systems, governance structures and practices based on collaborative philosophy / principles (e.g. mutual respect and trust, risk sharing reward, no blame culture, collective decision etc.)

\begin{tabular}{|c|c|c|}
\hline $\begin{array}{l}\text { Managing } \\
\text { contract } \\
\text { document }\end{array}$ & $\begin{array}{l}\text { The designer have the experience in managing the } \\
\text { processes and procedures for contract } \\
\text { administration (e.g. manage the negotiation, } \\
\text { execution, performance, modification and } \\
\text { termination of contracts) }\end{array}$ & $\begin{array}{l}\text { Elias et al. (2011); Gambatese et } \\
\text { al. (2017); Karakhan and } \\
\text { Gambatese (2017) }\end{array}$ \\
\hline $\begin{array}{l}\mathrm{PtD} \text { learning } \\
\text { experience }\end{array}$ & $\begin{array}{l}\text { The designer have the learning experience (e.g. } \\
\text { learned through } \mathrm{PtD} \text { specific / related subject (e.g. } \\
\text { Prevention through design / safe design concept) and } \\
\text { innovative teaching and learning) in their tertiary } \\
\text { education. }\end{array}$ & $\begin{array}{l}\text { Toole and Gambatese (2008); } \\
\text { Cortes et al., 2012; Behm et al., } \\
\text { (2014); Lopez-Arquillos et al. } \\
\text { (2015); Toole (2017); Din and } \\
\text { Gibson (2019); Abueisheh et al. } \\
\text { (2020) }\end{array}$ \\
\hline
\end{tabular}

Karakhan and Gambatese (2017); Manu et al. (2019)

(2020) 